\title{
A Literature Review: Acceptance Models for e-learning Implementation in Higher Institution
}

\author{
Kurniabudi*, Sharipuddin, Setiawan Assegaff \\ STIKOM Dinamika Bangsa Jambi, Jl. Jendral Soedirman, Jambi 36133, Indonesia \\ *kbudiz@yahoo.com
}

\begin{abstract}
This study investigates the conceptual model that has been used to measure the acceptance of e-learning technology applied in higher education. We conducted literature review study by collecting the papers from reputable journals. We used recognize database journal such as Google scholar, ProQuest, EBSCOhost, and IEEE to collect the articles. E-learning conceptual model is used as a keyword to search the relevant article. The selected articles are reviewed and analyzed. The result of analysis is presented. This study reveals that a famous conceptual model by Davis, Technology Acceptance Model (TAM), is used as reference in developing e-learning acceptance conceptual models.

Index Terms - e-learning, technology acceptance models, higher institution
\end{abstract}

\section{Introduction}

E-learning has become one of popular tools in learning activities today. Many organizations have adopted elearning because they believe e-learning has an ability to deliver information and knowledge more effectively and efficiently [1]. E-learning gives freedom to the participants to decide when and where they would like to conduct their learning activities. By providing 24 hour/day or full access services, E-learning is the most flexible tool to deliver course activities [2].

Nowadays, many higher institutions around the world have adopted e-learning. Some institutions have successfully adopted the e-learning system, however some others are failed. The previous studies in e-learning success implementation can identify the factors affecting the successful of this implementation [1, 3, 4].

It has become crucial for institution management to clearly understand in what condition and situation the elearning implementation will gain success [5].

This study reviews the concept and model that is proposed to support the successful adoption of e-learning in higher education. By reviewing the concept and the model, we hope to get advanced understanding about factors needed to focus on in implementation e-learning.

The article consists of four sections. First section is introduction, followed by literature review as the second section. The third section discusses the method applied in this study. The next section describes the review and analysis of the model. Asides, there will be also concepts used and applied in the study of e-learning success in higher education institution. The last section presents the conclusion.

\section{Literature Review}

\subsection{E-learning}

In general, e-learning is defined as electronic learning.
Normally, this means the use of information technology tool such as a computer to deliver information or knowledge or all part the course content, usually in university [2]. There are several benefits of e-learning. The benefits are, elearning participants have the freedom of time and place to access e-learning. E-learning infrastructure tends to be cheaper compared to physical infrastructure. E-learning can cover large participation of participants [6].

\subsection{Technology acceptance}

Technology acceptance is a mature field in IS research. Many strong theories have been shaped and applied in technology acceptance research. However, studies applying these theories have successfully identified factors that have significantly contributed in technology acceptance. Moreover, the findings enriched the understanding about people behavior in the acceptance of technology. In this section, we discuss theories in technology acceptance such as UTAT (Unified Theory of acceptance and use of Technology), TAM (Technology Acceptance Model), TPB (Theory Plan of Behavior) and TRA (theory of Reason Action).

\subsubsection{TAM (Technology Acceptance Model)}

Davis (1989) has instigated the technology acceptance model (TAM) as a tool to anticipate the prospect of a novel technology being implemented in an organization or a group [7]. This model has undoubtedly been the most recognized discussed model among all the others and is based on the theory of reasoned action.

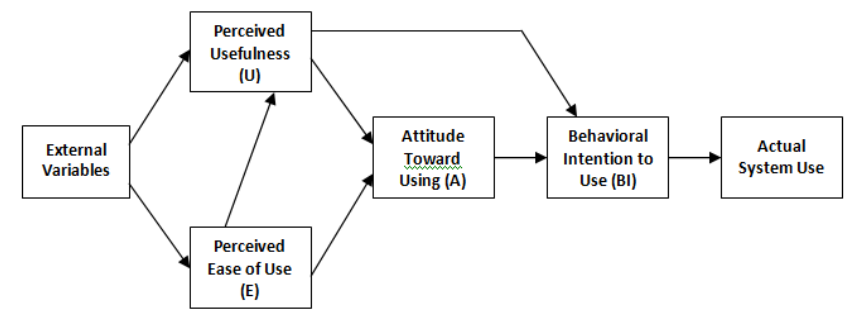

Fig. 1 Technology Acceptance Model (TAM)

Figure 1 illustrates the structures and main concepts of TAM and is defined by two beliefs; perceived ease of use which denotes the extent to which the potential user anticipate no efforts will be required by the target system, and perceived usefulness that is a potential user's subjective likelihood employing particular application system will upsurge one's job performance within an organizational context. TAM assumes that intention of use defines the usage of actual technology that consequently, is viewed as being mutually explained by the person's attitude towards perceived usefulness and the use of the technology. TAM 
hypothesized that the impacts of external features (including training, development process, system characteristics) on an intention to use are facilitated by perceived ease of use and perceived usefulness. The influence of perceived ease of use on perceived usefulness makes it more useful, according to TAM [7].

\subsubsection{Task Technology Fit}

Task-technology fit (TTF) theory argues that people are more intent to accept the technology if the capabilities of technology fit the need of the task from the people (Goodhue and Thompson, 1995). TTF as shown in Fig. 2 was developed under eight factors: quality, locatability, authorization, and compatibility, ease of use/training, production timeliness, systems reliability, and relationship with users. Every factor is measured by two until ten questions with responses on seven point linker scale ranging from strongly disagree to strongly agree [8].

TTF has been used in the various situations of information systems, such as e-commerce. TTF has also enriched other models related to IS outcomes such as the technology acceptance model (TAM). The purpose of the modifications was to fit the aim of the particular study.

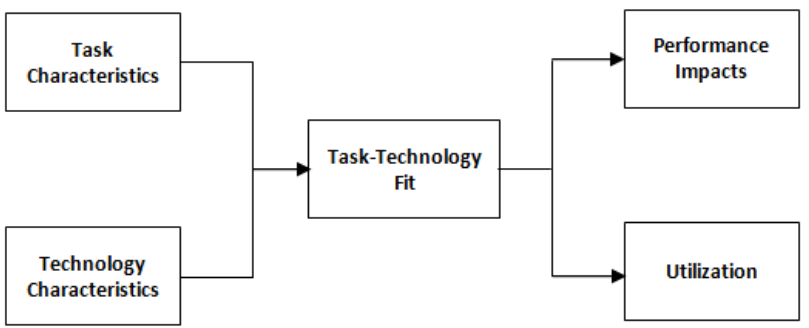

Fig. 2 Task Technology Fit

The principal construct of TTF Model is a formal construct known as Task-Technology Fit, which is the fitting of the abilities of the technology to the full support of the task [8]. The TTF models consist of four constructs, Task Characteristics, Technology Characteristics, which together affect the third construct Task-Technology Fit, which in turn affects the outcome variable, either Performance or Utilization.

\subsubsection{UTAUT}

The UTAUT is technology acceptance theory developed by Vekantesh et al. (2003) [9]. This theory argues that people using technology are affected by four key concepts (facilitating conditions, performance expectancy, social influence and effort expectancy). These factors are impact of direct causes of usage behavior and intention as described in Fig. 3.

This theory was developed under consolidation of eight models such as: social cognitive theory, theory of reasoned action, innovation diffusion theory, and technology acceptance model, model of PC utilization, theory of planned behavior, motivational model and a combined theory of planned behavior/technology acceptance model.

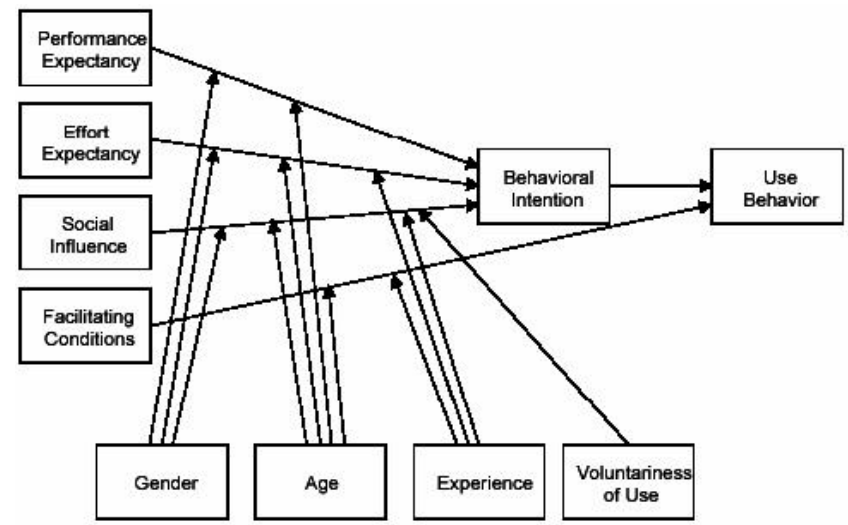

Fig. 3 UTAUT

\subsection{Strength and Limitation of The Technology Acceptance Theory}

TABLE 1 Strength and Limitation of Technology Acceptance Theory

\begin{tabular}{|c|c|c|}
\hline Theory & Strength & Limitation \\
\hline $\begin{array}{l}\text { Technology } \\
\text { Acceptance } \\
\text { Model (TAM) }\end{array}$ & $\begin{array}{l}\text { TAM is great to explain } \\
\text { attitude toward using } \\
\text { IS. } \\
\text { TAM predicts intention } \\
\text { of use and IS quite } \\
\text { well. } \\
\text { TAM is easier to use } \\
\text { and less expensive to } \\
\text { apply }\end{array}$ & $\begin{array}{l}\text { TAM supplies very } \\
\text { general information about } \\
\text { ease of usefulness }\end{array}$ \\
\hline TTF & $\begin{array}{l}\text { TTF models take a } \\
\text { decidedly rational } \\
\text { approach by assuming } \\
\text { that users choose to use } \\
\text { IT that provides } \\
\text { benefits, such as } \\
\text { improved job } \\
\text { performance, regardless } \\
\text { of their attitude toward } \\
\text { the IT (Goodhue 1995). } \\
\text { Both aspects, attitude } \\
\text { toward the IT and } \\
\text { rationally determined } \\
\text { expected consequences } \\
\text { from using the IT, are } \\
\text { likely to affect users } \\
\text { choices to use IT }\end{array}$ & $\begin{array}{l}\text { Does not consider effort } \\
\text { of using technology. Does } \\
\text { not consider the social } \\
\text { influences of using } \\
\text { technology. }\end{array}$ \\
\hline UTAT & $\begin{array}{l}\text { The most complete } \\
\text { acceptance model by } \\
\text { combining eight } \\
\text { existing models in one } \\
\text { model. }\end{array}$ & $\begin{array}{l}\text { This model needs to } \\
\text { consider more external } \\
\text { factors in different } \\
\text { technology area. }\end{array}$ \\
\hline
\end{tabular}

\section{Methodology}

This study is literature review study. We reviewed article from some reputable database journals such as: IEEEexplore, EBSCO, ProQuest and Google Scholar. We applied "E-learning conceptual Model" as a keyword. We found 60 articles, after reviewing the article's abstracts we selected 20 relevant papers. We did analysis on the articles and the result is described as finding in discussion part.

\section{Discussion}

Of the 20 papers chosen through the selection 
of abstract, we conducted an analysis in the methods used and the suitability of the research topics. We then found only 6 papers really fit in our research. Table 2 presents the research topics and authors using conceptual model for test the acceptance e-learning technology in higher education.

TABLE 2 Conceptual Model and Topic Research

\begin{tabular}{|c|c|c|c|}
\hline No. & Author & Topic & $\begin{array}{l}\text { Conceptual } \\
\text { Model }\end{array}$ \\
\hline 1 & $\begin{array}{l}\text { Farida } \\
\text { Umrani-Khan } \\
\text { and Sridhar } \\
\text { Iyer (2009) }\end{array}$ & $\begin{array}{l}\text { ELAM: a Model for } \\
\text { Acceptance and use of e- } \\
\text { learning by } \\
\text { Teachers and Students }\end{array}$ & $\begin{array}{l}\text { E-Learning } \\
\text { Acceptance } \\
\text { Model (ELAM) } \\
\text { develop base on } \\
\text { Unified Theory } \\
\text { of } \\
\text { Acceptance and } \\
\text { Use of } \\
\text { Technology } \\
\text { (UTAUT) }\end{array}$ \\
\hline 2 & $\begin{array}{l}\text { Byoung-Chan } \\
\text { Lee, Jeong-Ok } \\
\text { Yoon, In Lee } \\
(2009)\end{array}$ & $\begin{array}{l}\text { Learners' acceptance of } \\
\text { e-learning in South } \\
\text { Korea:Theories and } \\
\text { results }\end{array}$ & $\begin{array}{l}\text { Technology } \\
\text { Acceptance } \\
\text { Model (TAM) }\end{array}$ \\
\hline 3 & $\begin{array}{l}\text { MuneerAbbad } \\
\text {, Prince } \\
\text { Mohammad } \\
\text { Bin Fahd } \\
(2011)\end{array}$ & $\begin{array}{l}\text { A Conceptual Model of } \\
\text { Factors Affecting } \\
\text { eLearning Adoption }\end{array}$ & $\begin{array}{l}\text { Technology } \\
\text { Acceptance } \\
\text { Model (TAM) }\end{array}$ \\
\hline 4 & $\begin{array}{l}\text { Amer Al- } \\
\text { Adwan, } \\
\text { Ahmad Al- } \\
\text { Adwan and Jo } \\
\text { Smedley } \\
(2013)\end{array}$ & $\begin{array}{l}\text { Exploring students } \\
\text { acceptance of e-learning } \\
\text { using Technology } \\
\text { Acceptance } \\
\text { Model in Jordanian } \\
\text { universities }\end{array}$ & $\begin{array}{l}\text { Technology } \\
\text { Acceptance } \\
\text { Model (TAM) }\end{array}$ \\
\hline 5 & $\begin{array}{l}\text { Syed Afzal } \\
\text { Moshadi } \\
\text { Shah, } \\
\text { NaveedIdbal, } \\
\text { Dr. } \\
\text { SaquibYusafJ } \\
\text { anjua, Dr. } \\
\text { ShehuaAmjad } \\
\text { (2013) }\end{array}$ & $\begin{array}{l}\text { Employee Behavior } \\
\text { Towards Adoption of E- } \\
\text { learning Courses: } \\
\text { Validating Technology } \\
\text { Acceptance Mod }\end{array}$ & $\begin{array}{l}\text { Technology } \\
\text { Acceptance } \\
\text { Model (TAM) }\end{array}$ \\
\hline 6 & $\begin{array}{l}\text { Chih-Min Ma, } \\
\text { Cheng-Min } \\
\text { Chao and Bor- } \\
\text { Wen Cheng } \\
\text { (2013) }\end{array}$ & $\begin{array}{l}\text { Integrating Technology } \\
\text { Acceptance Model and } \\
\text { Task-technology Fit into } \\
\text { Blended E-Learning } \\
\text { System }\end{array}$ & $\begin{array}{l}\text { Technology } \\
\text { Acceptance } \\
\text { Model (TAM) } \\
\text { and Task } \\
\text { Technology Fit } \\
\text { (TTF) }\end{array}$ \\
\hline
\end{tabular}

Based on the review result of the papers in Table 1, it is found that every researcher has different research focus in using model concept to measure the acceptance of elearning technology. Umrani-Khan and Iyer (2009) use ELAM (e-learning acceptance model) to identify the key factors in the acceptance of e-learning as measured by behavioral intention to use the technology and actual usage [10]. The four determinants of e-learning acceptance are (i) performance expectancy, (ii) effort expectancy, (iii) social influence, and (iv) facilitating conditions. Lee, et al. (2009) analyzed the relationship among the three service quality constructs (instructor characteristics, teaching materials, and design of learning content) and between the two-belief constructs (perceived usefulness and perceived ease of use) [11]. They then analyzed flow of construct (playfulness) and intention to use in learning. Abbad and Fahd (2011) indicate that external variables such as subjective norms, Internet experience, system interactivity, self-efficacy and technical support have an influence on technology acceptance [12]. Al-Adwan, et al. (2013) provide an indicator of students' acceptance of e-learning as well as identification of the important factors that would contribute to its successful use [13]. The factors are: Perceived usefulness (PU), Perceived ease of use (PEOU), Intention to use (ITU) and Attitude towards use (ATU). Shah, et al. (2013) used TAM to investigate the acceptance of e-learning by student at Institute Bankers Pakistan (IBP) [14]. The research finding in learning style and age indicate positive association with Perceived ease of use whereas learning style alone is positively correlated with Perceived Usefulness. Ma, et al. (2013) found that perceived usefulness is an important factor affecting the behavioral intention to use a BELS (Blended E-Learning System) [15]. The TTF was expected to directly influence perceived usefulness.

Although each researcher has different discussion focus, the concept model used by those researchers in measuring the acceptance of e-learning technology in higher education is almost the same. Those researchers used Unified Theory of Acceptance and Technology (UTAUT), Task Technology Fit (TTF), and Technology Acceptance Model (TAM) for measuring technology elearning acceptance. We found that TAM is a concept model that is most widely used.

\section{Conclusion}

The main objective of this research is to get understanding of theories and model concept used to measure the acceptance of technology. The theory discussion in literature review gives an overview of the utilization of model concept to measure the acceptance of technology. This paper has also discussed several research topics related to e-learning technology acceptance in higher education. This study found that the concept model which is used most widely for measuring e-learning technology acceptance was TAM.

\section{References}

[1] K. A. Pituch and Y.-k. Lee, "The influence of system characteristics on e-learning use," Computers \& Education, vol. 47, pp. 222-244, 2006.

[2] D. R. Garrison, E-learning in the 21st Century: A Framework for Research and Practice: Taylor \& Francis, 2011.

[3] T. Govindasamy, "Successful implementation of e-learning: Pedagogical considerations," The Internet and Higher Education, vol. 4, pp. 287-299, 2001.

[4] J. B. Williams and J. Jacobs, "Exploring the use of blogs as learning spaces in the higher education sector," Australasian Journal of Educational Technology, vol. 20, pp. 232-247, 2004.

[5] N. L. Wagner, K. Hassanein, and M. M. Head, "Who is responsible for e-learning success in higher education? a stakeholders' analysis," Educational Technology \& Society, vol. 11, pp. 26-36, 2008.

[6] S.-S. Liaw, "Investigating students' perceived satisfaction, behavioral intention, and effectiveness of e-learning: A case study of the Blackboard system," Computers \& Education, vol. 51, pp. 864-873, 2008.

[7] F. D. Davis, "Perceived usefulness, perceived ease of use, and user acceptance of information technology," MIS Quarterly, vol. 13, pp. 319-340, 1989.

[8] D. L. Goodhue and R. Thompson, "Task-technology fit," Humancomputer interaction and management information systems: applications. New York: Sharpe, pp. 184-204, 2006.

[9] V. Venkatesh, M. G. Morris, G. B. Davis, and F. D. Davis, "User acceptance of information technology: Toward a unified view," MIS 
quarterly, pp. 425-478, 2003.

[10] F. Umrani-Khan and S. Iyer, "ELAM: a model for acceptance and use of e-learning by teachers and students", Proceedings of the International Conference on e-Learning, p475-485 2009.

[11] B-C. Lee, J-O. Yoon, I. Lee, "Learners' acceptance of e-learning in South Korea: Theories and results", Computer \& Education, pp. 1320-1329, 2009.

[12] M. Abbad and P. M. B. Fahd," A conceptual model of factors affecting e-learning adoption", IEEE, pp. 1108-1119, 2011.

[13] A. Al-Adwan, A. Al-Adwan, and J. Smedley, "Exploring students acceptance of e-learning using technology acceptance model in Jordanian universities", International Journal of Education and Development using Information and Communication Technology (IJEDICT), vol. 9, no. 2, pp. 4-18, 2013.

[14] S. A. M. Shah, N. Idbal, S. Y. Janjua, S. Amjad, "Employee behavior towards adoption of e-learning couses: validating technology acceptance mod", Mediterranean Journal of Social Sciences, vol. 4, no. 14, pp. 765-774, 2013.

[15] C-M. Ma, C-M. Chao, and B-W. Cheng, "Integrating technology acceptance model and task-technology fit into blended e-learning system", Journal of Applied Sciences, vol. 13, no. 5, pp. 736-742, 2013. 